AL IBTIDA: JURNAL PENDIDIKAN GURU MI (2018) Vol 5 (1) : 25-38

DOI: http://dx.doi.org/ 10.24235/al.ibtida.snj.v5i1.2479

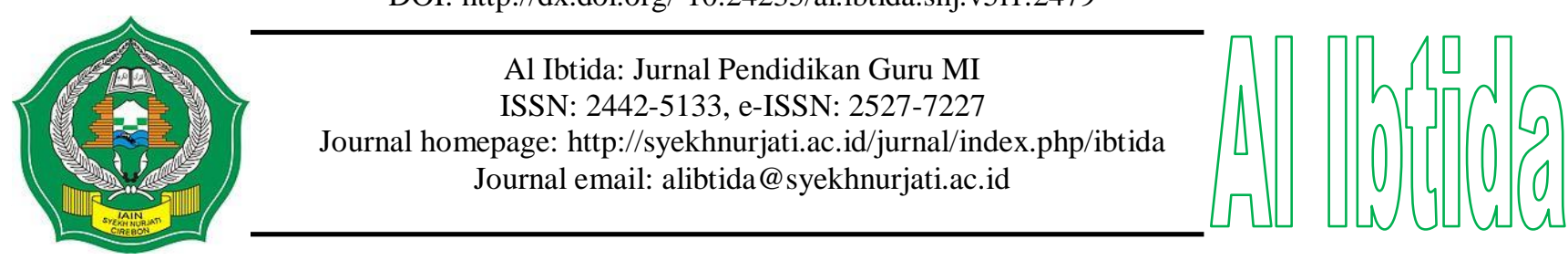

\title{
Respon Stakeholders Terhadap Kurikulum Berbasis Kerangka Kualifikasi Nasional Indonesia (KKNI) Jurusan PGMI IAIN Syekh Nurjati Cirebon
}

\author{
Moh Masnun* \\ *Program Studi Pendidikan Guru Madrasah Ibtidaiyah, Fakultas Ilmu Tarbiyah dan Keguruan, \\ IAIN Syekh Nurjati Cirebon \\ Email: mohmasnun10@gmail.com \\ Syibli Maufur** \\ **Program Studi Pendidikan Guru Madrasah Ibtidaiyah, Fakultas Ilmu Tarbiyah dan Keguruan, \\ IAIN Syekh Nurjati Cirebon \\ Email: syiblimaufur@gmail.com \\ Ahmad Arifuddin*** \\ ***Program Studi Pendidikan Guru Madrasah Ibtidaiyah, Fakultas Ilmu Tarbiyah dan Keguruan, \\ IAIN Syekh Nurjati Cirebon \\ Email: arief.udien4@gmail.com
}

Received 11 February 2018; Received in revised form: 25 May 2018 ; Accepted 26 May 2018

Publish Online: 28 June 2018

\begin{abstract}
Abstrak
Lahirnya KKNI dan SN DIKTI menuntut sebuah program studi, termasuk di dalamnya program studi Pendidikan Guru Madrasah Ibtidaiyah (PGMI) Fakultas Ilmu Tarbiyah dan Keguruan IAIN Syekh Nurjati Cirebon untuk segera meredesain kurikulumnya menjadi kurikulum yang mengacu KKNI dan SN DIKTI. Penelitian ini bertujuan untuk mendeskripsikan respon stakeholders (pihak dosen, kepala MI, dan Kementerian Agama Kota Cirebon) terhadap kurikulum jurusan PGMI yang mengacu KKNI dan SN DIKTI. Penelitian ini merupakan penelitian lapangan (field research) yang bersifat deskriptif kualitatif. Dimana dalam penelitian ini, peneliti mencari dan menggunakan data-data yang bersifat deskriptif yaitu berupa kata-kata atau ungkapan, pendapat-pendapat dari subyek penelitian, baik itu kata-kata secara lisan maupun tulisan. Pengumpulan data dilakukan dengan metode wawancara dan dokumentasi. Teknik analisis dimulai dengan reduksi data, penyajian data, dan menarik kesimpulan. Analisis data dilakukan sewaktu pengumpulan data dan setelah semua data terkumpul atau setelah selesai penelitian di lapangan. Hasil penelitian menunjukkan bahwa secara umum respon stakeholders (dosen jurusan PGMI, Kepala MI Kota Cirebon, dan Kasi Pendidikan Madrasah Kementerian Agama Kota Cirebon) terhadap kurikulum berbasis KKNI jurusan PGMI sudah baik dan sangat layak diimplementasikan di jurusan PGMI. Namun stakeholders memberikan rekomendasi agar ditambahkan satu mata kuliah baru, yaitu psikologi kepribadian dan hubungan sosial serta penambahan bobot sks pada mata kuliah keahlian profesi seperti perencanaan pembelajaran dan praktik pengalaman lapangan.
\end{abstract}

Kata kunci: respon stakeholders, kurikulum berbasis KKNI, PGMI 


\begin{abstract}
The birth of KKNI and SN DIKTI demanded a study program, including the study program of Madrasah Ibtidaiyah Teachers (PGMI) Faculty of Tarbiyah and Training Teacher IAIN Syekh Nurjati Cirebon to immediately redesign the curriculum into a curriculum referring to KKNI and SN DIKTI. This study aims to describe the response of stakeholders (the lecturers, the head of MI, and the ministry of religion of Cirebon city) to the curriculum of PGMI which refers to KKNI and SN DIKTI. This research is a field research (field research) which is descriptive qualitative. Where in this study, researchers search and use data that is descriptive in the form of words or phrases, opinions of research subjects, both words orally and in writing. Data collection was done by interview and documentation method. Analytical techniques begin with data reduction, data presentation, and draw conclusions. Data analysis is during data collection and after all data collected or after completion of research in the field. The results showed that generally the response of stakeholders (the lecturers of PGMI, the head of MI, and the ministry of religion affairs of Cirebon city) to the curriculum of PGMI department which refers to KKNI is good and very feasible implemented in the PGMI department. However, stakeholders recommend that a new subject be added, that is personality psychology and social relationships and the addition of sks weight to professional proficiency courses such as lesson planning and field experience practice. But stakeholders recommended that a new course have to added, such as the psychology of personality and social relationships and the addition of sks weight on professional skills courses such as lesson planning and field experience practice.
\end{abstract}

Keywords: responses of stakeholder, curriculum based on KKNI, PGMI department

\title{
PENDAHULUAN
}

Terbitnya Peraturan Presiden RI No 8 tahun 2012 dan Permendikbud RI No 73 tahun 2013 mengharuskan sebuah perguruan tinggi untuk melakukan redesain kurikulumnya. Redesain kurikulum tersebut terkait dengan pengembangan kurikulum berbasis Kerangka Kualifikasi Nasional Indonesia yang kemudian disingkat KKNI.

Menurut Peraturan Presiden RI No 8 tahun 2012 pasal 1, yang dimaksud dengan KKNI adalah kerangka penjenjangan kualifikasi kompetensi yang dapat menyandingkan, menyetarakan, dan mengintegrasikan antara bidang pendidikan dengan bidang pelatihan kerja serta pengalaman kerja dalam rangka pemberian pengakuan kompetensi kerja sesuai dengan struktur pekerjaan di berbagai sektor. Sementara itu, menurut tim penyusun Buku Kurikulum Pendidikan Tinggi dalam (Khodijah, 2016) KKNI merupakan perwujudan mutu dan jati diri Bangsa Indonesia terkait dengan sistem pendidikan nasional dan pelatihan yang dimiliki negara Indonesia. Menurut (Sutrisno \& Suyadi, 2015) KKNI terdiri atas 9 (sembilan) jenjang kualifikasi, dimulai dari jenjang 1 (satu) sebagai jenjang terendah sampai dengan jenjang 9 (sembilan) sebagai jenjang tertinggi. Penetapan penjenjangan 1 hingga 9 ini didasarkan pada kondisi ketenagakerjaan di Indonesia ditinjau dari aspek kebutuhan penghasil (supply push) maupun pengguna (demand pull) tenaga kerja. Deskriptor setiap jenjang kualifikasi juga disesuaikan dengan mempertimbangkan kondisi negara secara menyeluruh, termasuk 
perkembangan ilmu pengetahuan, teknologi, dan seni. Di samping itu, deskriptor generik setiap kualifikasi juga mempertimbangkan perkembangan pada sektor-sektor pendukung perekonomian dan kesejahteraan rakyat seperti perindustrian, pertanian, kesehatan, hukum dan lain sebagainya.

Lebih lanjut sutrisno dan suyadi (2015) menjelaskan bahwa pada setiap jenjang kualifikasi KKNI terdiri dari empat indikator, yaitu pertama, keterampilan kerja. Keterampilan kerja adalah kemampuan yang dimiliki oleh seseorang yang meliputi ranah kognitif, ranah psikomotorik dan ranah afektif yang tercermin secara utuh dalam perilaku atau dalam melaksanakan suatu pekerjaan. Kedua, cakupan keilmuan/pengetahuan. Cakupan keilmuan/pengetahuan adalah rumusan tingkat keluasan, kedalaman, dan kerumitan/kecanggihan pengetahuan tertentu yang harus dimiliki. Jadi, semakin tinggi jenjang kualifikasi seseorang dalam KKNI, maka semakin luas, dalam dan semakin canggih pengetahuan/keilmuan yang dimilikinya. Ketiga, metode dan tingkat kemampuan. Metode dan tingkat kemampuan adalah cara memanfaatkan ilmu pengetahuan, keahlian, dan metode yang harus dikuasai dalam melakukan suatu tugas atau pekerjaan tertentu, termasuk di dalamnya adalah kemampuan berpikir. Jadi, semakin tinggi jenjang kualifikasi seseorang dalam KKNI, maka semakin terampil menggunakan berbagai metode dan ilmu penegtahuan untuk menyelesaikan tugas-tugasnya. Keempat, kemampuan manajerial. Kemampuan manajerial adalah kemampuan dan sikap seseorang yang diisyaratkan dalam melakukan suatu tugas atau pekerjaan, serta tingkat tanggung jawab dalam bidang kerja tersebut. Pada setiap jenjang kualifikasi di KKNI memiliki kesetaraan dengan capaian pembelajaran yang dihasilkan melalui pendidikan, pelatihan kerja atau pengalaman kerja (Peraturan Presiden RI No 8, 2012).

Selanjutnya menurut Permendikbud RI No 73 tahun 2013 pasal 2, KKNI bidang pendidikan tinggi merupakan kerangka penjenjangan kualifikasi yang dapat menyandingkan, menyetarakan, dan mengintegrasikan capaian pembelajaran dari jalur pendidikan nonformal, pendidikan informal, dan atau pengalaman kerja ke dalam jenis dan jenjang pendidikan tinggi. Penjenjangan kualifikasi tersebut dimaksudkan untuk memfasilitasi pendidikan seseorang yang mempunyai pengalaman kerja atau memiliki capaian pembelajaran dari pendidikan nonformal atau pendidikan informal untuk menempuh pendidikan formal ke jenjang/tingkat yang lebih tinggi dan/atau mendapatkan pengakuan kualifikasi lulusan jenis pendidikan tertentu dari perguruan tinggi.

Lahirnya KKNI ini didasari oleh tuntutan global terkait dengan diberlakukannya Masyarakat Ekonomi Asean (MEA) tahun 2015 (Waseso \& Hidayat, 2017). Dengan diberlakukannya MEA ini maka pertukaran tenaga kerja di negara-negara asia tenggara tidak terelakkan lagi. Atas dasar tersebut, maka pendidikan tinggi di Indonesia harus mampu mencetak lulusan-lulusan yang siap kerja dan mampu berkompetisi dengan lulusan-lulusan pendidikan 
tinggi di Negara-negara asia tenggara lainya (Hasan, 2015). Hal ini senada dengan apa yang dikemukakan oleh (Hatten \& Rosental, 2001) bahwa yang perlu mendapat dukungan besar dalam rangka menjawab tantangan global adalah tersedianya tenaga kerja terampil dalam kadar yang memadai agar masyarakat mampu meningkatkan kreativitasnya.

Tak luput dari itu, Jurusan Pendidikan Guru Madrasah Ibtidaiyah (PGMI) Fakultas Ilmu Tarbiyah dan Keguruan IAIN Syekh Nurjati Cirebon sebagai salah satu program studi yang mencetak calon guru MI/SD dituntut untuk segera meredesain kurikulumnya menjadi kurikulum berbasis KKNI. Penyusunan kurikulum berbasis KKNI di Jurusan PGMI ini diawali dengan pembentukan tim pengembang kurikulum yang kemudian disyahkan oleh pimpinan fakultas. Dalam penyusunannya, tim pengembang kurikulum jurusan PGMI mengacu pada capaian pembelajaran (Learning Outcomes) yang dihasilkan oleh Asosiasi Dosen PGMI (AD PGMI) Indonesia.

Capaian pembelajaran yang didapatkan dari AD PGMI Indonesia kemudian dianalisis dan diturunkan ke dalam bahan kajian yang diperlukan untuk mencapai capaian pembelajaran tersebut. Setelah menentukan bahan kajian yang diperlukan, maka selanjutnya bahan kajian tersebut dipetakan sesuai dengan rumpun keilmuannya serta untuk mengetahui tingkat kedalaman dari bahan kajian tersebut. Setelah memetakan bahan kajian dan mengetahui tingkat kedalaman dari bahan kajian tersebut, maka tahap selanjutnya adalah menentukan judul mata kuliah beserta bobot SKSnya.

Dari rangkaian kegiatan penyusunan kurikulum berbasis KKNI tersebut, maka dihasilkanlah sebuah draft kurikulum jurusan PGMI berbasis KKNI. Menurut hemat kami sebagai tim pengembang kurikulum jurusan PGMI dipandang perlu untuk dilakukan analisis mendalam oleh stakeholders apakah kurikulum yang telah disusun tersebut sesuai dengan kebutuhan stakeholders atau tidak, sudah sesuai dengan tuntutan perkembangan abad 21 atau tidak, agar lulusan jurusan PGMI mampu menjadi calon guru MI/SD yang professional sesuai dengan tuntutan perkembangan zaman.

Penelitian yang relevan telah dilakukan oleh (Arifuddin \& Fatimah, 2016) tentang Respon Dosen terhadap Kebijakan Implementasi Kurikulum 2013 di Sekolah/Madrasah (Studi Pada Dosen FTIK IAIN Palu). Menurutnya, respon dosen terhadap kebijakan implementasi kurikulum 2013 tergolong masih rendah, yakni hanya 34\% dosen yang merespon secara aktif dengan melakukan penguatan materi perkuliahan berperspektif kurikulum 2013. Sedangkan 66\% dosen merespon pasif, yakni hanya melalui instruksi tugas kepada mahasiswa untuk mencari informasi dan pengetahuan secara mandiri mengenai konsep dan pembelajaran kurikulum 2013. Penguatan materi berperspektif kurikulum 2013 yang dilakukan dosen di Lingkungan Fakultas Tarbiyah dan Ilmu Keguruan (FTIK) IAIN Palu, selain dengan memberikan penguatan 
pengetahuan materi secara teoritis, juga tugas lapangan untuk menyesuaikan teori di kelas dengan konsep yang diimplementasikan oleh guru di sekolah/madrasah.

Penelitian lain yang cukup relevan juga telah dilakukan oleh (Supriyadi, 2012) tentang Kajian Kurikulum Jurusan Pendidikan Teknik Elektro Fakultas Teknik Universitas Negeri Yogyakarta Mengacu Pada KKNI. Menurutnya hasil evaluasi terhadap pelaksanaan kurikulum di jurusan Pendidikan Teknik Elektro tergolong cukup baik. Hasil kesesuaian kurikulum ditinjau secara akumulatif berdasarkan respon dosen/alumni diperoleh sebesar 75,81\% dengan kategori sesuai. Sementara itu, berdasarkan respon mahasiswa diperoleh sebesar 64,64\% dengan kategori cukup sesuai.

Dari latar belakang di atas, maka kami memandang perlu untuk melakukan penelitian dengan judul "Respon Stakeholdesr Terhadap Kurikulum Berbasis Kerangka Kualifikasi Nasional Indonesia (KKNI) Jurusan PGMI Fakultas Ilmu Tarbiyah dan Keguruan IAIN Syekh Nurjati Cirebon Tahun 2017". Penelitian ini bertujuan untuk mendeskripsikan respon stakeholders (dosen Jurusan PGMI, Kepala Madrasah MI Kota Cirebon dan Kasi Pendidikan Madrasah Kementerian Agama Kota Cirebon) terhadap kurikulum berbasis KKNI dan SN DIKTI Jurusan PGMI. Respon stakeholders ini sangat diperlukan dalam rangka penyempurnaan kurikulum berbasis KKNI dan SN DIKTI Jurusan PGMI Fakultas Ilmu Tarbiyah dan Keguruan IAIN Syekh Nurjati Cirebon.

\section{METODE PENELITIAN}

Penelitian ini merupakan penelitian lapangan (field research) yang bersifat deskriptif kualitatif. Penelitian kualitatif adalah penelitian yang dilakukan secara wajar dan natural sesuai kondisi obyektif di lapangan tanpa adanya manipulasi, serta jenis data yang dikumpulkan terutama data kualitatif (Arifin, 2011). Dalam penelitian ini, peneliti mencari dan menggunakan data-data yang bersifat deskriptif yaitu berupa kata-kata atau ungkapan, pendapat-pendapat dari subyek penelitian, baik itu kata-kata secara lisan maupun tulisan. Pendekatan dalam penelitian ini menggunakan pendekatan fenomenologis, yaitu peneliti berusaha untuk memahami fenomena arti peristiwa dan kaitan-kaitan terhadap orang-orang dalam situasi tertentu. Penelitian dengan pendekatan fenomenologis ini berusaha memahami arti peristiwa dan kaitan-kaitannya terhadap orang-orang biasa dalam situasi tertentu atau aspek subjektif dari perilaku seseorang (Moloeng, 2000). Fenomenologi juga berupaya mengungkapkan tentang makna dari pengalaman seseorang (Hasbiansyah, 2008).

Penelitian ini bertempat di Jurusan Pendidikan Guru MI (PGMI) Fakultas Ilmu Tarbiyah dan Keguruan IAIN Syekh Nurjati Cirebon dan beberapa Madrasah Ibtidaiyah di Kota Cirebon (MI An Nur, MI Salafiyah, MI Al Hidayah, MIN Kota Cirebon, MI Hidayatus Syibyan) serta 
Kementerian Agama Kota Cirebon. Adapun waktu yang dibutuhkan dalam penelitian ini adalah 3 bulan, yaitu dari bulan Agustus s.d Oktober 2017. Untuk menentukan sumber data pada penelitian ini digunakan teknik purposive sampling, yaitu teknik pengambilan sampel sumber data dengan pertimbangan tertentu (Soegiyono, 2013).

Adapun teknik pengumpulan data dalam penelitian ini adalah teknik wawancara dan dokumentasi. Metode wawancara dalam penelitian ini digunakan sebagai metode pengumpulan data utama. Wawancara merupakan salah satu metode pengumpulan data dengan cara komunikasi antara pengumpul data dengan sumber data. Melalui wawancara, responden diberi kesempatan untuk menjelaskan pendapatnya, serta menceritakan pengalaman dan pengamatan mereka sendiri (Nurdiani, 2014).

Sementara itu, sumber data dalam penelitian ini adalah dosen PGMI, kepala madrasah ibtidaiyah di kota Cirebon dan Kasi Pendidikan Madrasah/Sekolah Kementerian Agama Kota Cirebon. Point-point pertanyaan yang diajukan kepada narasumber/data diantaranya adalah tentang sinkronisasi visi, misi dan tujuan jurusan PGMI, profil lulusan, capaian pembelajaran, komponen mata kuliah, kompetensi lulusan, bobot sks, softskill yang dikembangkan pada setiap mata kuliah, deskripsi mata kuliah, dan penempatan mata kuliah pada setiap semester. Sementara itu, metode dokumentasi adalah suatu metode untuk mencari data variabel yang berupa catatancatatan penting, transkip, buku, prasasti dan lain sebagainya (Zulaikha \& Khair, 2016). Dokumentasi yang digunakan oleh peneliti meliputi lembar pertanyaan wawancara dan foto saat wawancara dengan sumber data.

Setelah data diperoleh kemudian data tersebut diuji keabsahannya menggunakan teknik pemeriksaan triangulasi data. Triangulasi data merupakan teknik pengecekan data dari berbagai sumber, dari berbagai cara, dan dari berbagai waktu (Soegiyono, 2013). Namun dalam penelitian ini, triangulasi data yang dilakukan menggunakan teknik triangulasi sumber dan teknik. Kegiatan triangulasi dilakukan peneliti dengan membandingkan data yang diperoleh melalui setting waktu dan instrumen yang berbeda dengan jalan membandingkan data hasil pengamatan dengan data hasil wawancara, membandingkan hasil wawancara dengan isi suatu dokumen.

Selanjutnya, analisis data dalam penelitian kualitatif ini dilakukan pada saat pengumpulan data berlangsung dan setelah pengumpulan data. Menurut Miles and Huberman dalam (Soegiyono, 2013) menjelaskan bahwa aktivitas dalam analisis data kualitatif dilakukan secara terus menerus sampai tuntas, sehingga datanya sudah jenuh. Adapun analisis data dalam penelitian ini dimulai dari lapangan dengan menggunakan metode deskriptif analitik, yaitu menyusun dengan cara mendiskripsikan, menafsirkan data dan semua hal yang menjadi fokus dalam penelitian. 


\section{HASIL DAN PEMBAHASAN}

\section{A. Respon Dosen Terhadap Kurikulum Berbasis KKNI Jurusan PGMI}

Berdasarkan hasil wawancara dengan dosen jurusan PGMI Fakultas Ilmu Tarbiyah dan Keguruan IAIN Syekh Nurjati Cirebon diperoleh informasi bahwa respon dosen jurusan PGMI terhadap kurikulum berbasis KKNI jurusan PGMI pada aspek visi, misi, dan tujuan sudah sangat sesuai. Menurutnya, visi, misi, dan tujuan jurusan PGMI sudah saling menguatkan serta memuat kebutuhan masyarakat di abad 21, yakni karakter, berpikir kritis, kreatif dan kolaboratif. Visi jurusan PGMI sudah menekankan pada profesionalisme lulusan serta daya saing lulusannya. Visi tersebut juga sudah terejawantahkan pada misi dan tujuan jurusan PGMI yang mengandung unsur tridharma perguruan tinggi, yakni pendidikan dan pengajaran, penelitian dan pengabdian kepada masyarakat serta aspek penunjang dari thidharma perguruan tinggi tersebut.

Sementara itu, pada aspek profil lulusan jurusan PGMI, dosen jurusan PGMI juga merespon sangat sesuai. Profil lulusan jurusan PGMI sudah sesuai dengan kebutuhan pasar "marketable", yakni lulusan jurusan PGMI tidak hanya diarahkan untuk menjadi guru kelas saja, tetapi juga diarahkan untuk menjadi peneliti dan edutainment. Hal ini juga sesuai dengan hasil musyawarah perkumpulan dosen PGMI Indonesia di UIN Ar Raniry Banda Aceh pada tanggal 20-22 Mei 2017 yang menetapkan guru kelas di MI/SD sebagai profil lulusan utama jurusan PGMI.

Selanjutnya, pada aspek capaian pembelajaran dosen jurusan PGMI merespon sudah sesuai dengan bahan kajian yang diperlukan. Bahan kajian sudah baik dan tepat apabila diaplikasikan dalam proses pembelajaran di kelas maupun di luar kelas. Menurutnya bahan kajian yang tercantum di draf kurikulum berbasis KKNI jurusan PGMI sudah komprehenshif dan mampu mengantarkan mahasiswa untuk mencapai learning outcomes yang telah ditetapkan. Bahan kajian juga sudah dikelompokkan sesuai dengan rumpun keilmuannya masing-masing, mulai dari rumpun keilmuan ilmu pendidikan islam, humaniora, pendidikan umum, psikologi, kebahasaan, manajemen, MIPA, IPS, seni budaya, metodologi penelitian, statistik hingga filsafat pendidikan islam.

Kemudian pada aspek komponen mata kuliah, dosen jurusan PGMI merespon sudah sangat sesuai dengan kebutuhan stakeholders. Komponen mata kuliah di draft kurikulum berbasis KKNI jurusan PGMI sudah mampu mengarahkan mahasiswa untuk menguasai empat kompetensi sebagai seorang pendidik, yakni pertama, kompetensi kepribadian dibekali dengan mata kuliah-mata kuliah keislaman, diantaranya mata kuliah studi qur'an, studi hadits, aqidah akhlaq, ilmu pendidikan islam, dan lain sebagainya. Kedua, kompetensi paedagogik dibekali dengan mata kuliah-mata kuliah keahlian jurusan, diantaranya 
pembelajaran matematika MI, Pembelajaran IPS MI, Pembelajaran IPA MI, Pembelajaran PKn MI, Pembelajaran Tematik, Pembelajaran Tarikh di MI, pembelajaran bahasa arab, fiqh, qur'an hadits, Seni drama dan tari, penjaskes di MI, dan lain sebagainya. Ketiga, kompetensi profesional dibekali dengan mata kuliah-mata kuliah Etika Profesi Keguruan, Ushul al Tarbiyah, Strategi Pembelajaran, media pembelajaran, micro teaching, evaluasi pembelajaran, dan lain sebagainya. Keempat, kompetensi sosial dibekali dengan mata kuliah PPL, KKN, dan lain sebagainya. Oleh karena itu, untuk saat ini tidak perlu ditambahkan lagi mata kuliah baru, namun menurutnya mata kuliah yang diajarkan di jurusan PGMI harus diarahkan bersifat praksis, bukan teoretis semata agar mahasiswa setelah lulus dari jurusan PGMI dapat dengan mudah menerapkannya di sekolah dasar/madrasah ibtidaiyah. Hal ini sesuai dengan konsep KKNI.

Pada aspek bobot sks mata kuliah, dosen jurusan PGMI merespon sudah cukup sesuai. Akan tetapi mereka menyarankan agar untuk mata kuliah penciri jurusan PGMI (Akidah akhlaq, Qur'an Hadits, dan lain sebagainya) serta mata kuliah yang bersifat praksis perlu ditambah bobot sks nya, agar lulusan jurusan PGMI lebih unggul dan berkualitas dibandingkan dengan lulusan jurusan yang sejenis serta mampu memenuhi kebutuhan masyarakat. Bobot sks hendaknya juga harus disesuaikan dengan level/jenjang KKNI untuk strata 1 (sarjana), yakni level analisis, sintesis dan create. Kemudian terkait dengan aspek softskill yang dikembangkan di setiap mata kuliah, dosen jurusan PGMI merespon sudah sangat sesuai dan sesuai. Softskill yang dikembangkan di draft kurikulum berbasis KKNI jurusan PGMI diantaranya adalah bertakwa kepada Tuhan Yang Maha Esa dan mampu menunjukkan sikap religius mampu melakukan proses evaluasi diri terhadap kelompok kerja yang berada di bawah tanggung jawabnya, dan mampu mengelola pembelajaran secara mandiri, mampu mendokumentasikan, menyimpan, mengamankan, dan menemukan kembali data untuk menjamin kesahihan dan mencegah plagiasi, mampu menerapkan pemikiran logis, kritis, sistematis, dan inovatif dalam konteks pengembangan atau implementasi ilmu pengetahuan dan teknologi yang memperhatikan dan menerapkan nilai humanoria yang sesuai dengan bidang keahliannya, menginternalisasi nilai, norma, dan etika akademik, menghargai keanekaragaman budaya, pandangan, agama, dan kepercayaan, serta pendapat atau temuan orisinal orang lain, berperan sebagai warga negara yang bangga dan cinta tanah air, memiliki nasionalisme serta rasa tanggungjawab pada negara dan bangsa, berkontribusi dalam peningkatan mutu kehidupan bermasyarakat, berbangsa, bernegara dan kemajuan peradaban berdasarkan Pancasila, dan lain sebagainya.

Terkait dengan deskripsi mata kuliah, dosen jurusan PGMI merespon sudah sesuai dengan keluasan dan kedalaman mata kuliah tersebut. Deskripsi mata kuliah sudah 
mencerminkan konten/isi mata kuliah yang akan diajarkan kepada mahasiswa. Deskripsi mata kuliah juga sudah mencerminkan capaian pembelajaran yang hendak dicapai pada setiap mata kuliah. Namun untuk mata kuliah pendidikan multikultural hendaknya lebih menekankan pada keberagamaan budaya dan persatuan di atas keberagaman tersebut.

Terakhir, pada aspek penempatan mata kuliah pada setiap semester, menurutnya sudah sangat sesuai, karena sudah hirarkis dan sistematis. Penempatan mata kuliah diawali dari mata kuliah wajib nasional, mata kuliah penciri perguruan tinggi, mata kuliah fakultas dan mata kuliah program studi. Penempatan mata kuliah juga sudah memperhatikan tingkat kesulitan mata kuliah, tingkat perkembangan mahasiswa, kebutuhan lapangan, dan lain sebagainya.

Dari uraian hasil wawancara di atas dapat disimpulkan bahwa respon dosen jurusan PGMI terhadap kurikulum berbasis KKNI jurusan PGMI sudah baik dan sangat layak diimplementasikan di jurusan PGMI Fakultas Ilmu Tarbiyah dan Keguruan IAIN Syekh Nurjati Cirebon. Draft kurikulum berbasis KKNI jurusan PGMI sudah mengarahkan mahasiswa jurusan PGMI untuk menguasai empat kompetensi seorang pendidik, yakni kompetensi kepribadian, kompetensi profesional, kompetensi paedagogik dan kompetensi sosial. Selain itu, draft kurikulum berbasis KKNI jurusan PGMI juga sudah menekankan pada penguasaan level/jenjang KKNI untuk strara 1 (sarjana) yakni level analisis, sintesis dan create.

\section{B. Respon Pihak Sekolah Terhadap Kurikulum Berbasis KKNI Jurusan PGMI}

Berdasarkan hasil wawancara dengan kepala madrasah ibtidaiyah (MI) di Kota Cirebon diperoleh bahwa respon kepala madrasah MI di Kota Cirebon terhadap kurikulum berbasis KKNI jurusan PGMI pada aspek visi, misi, dan tujuan sudah sesuai. Menurutnya, visi, misi, dan tujuan jurusan PGMI sudah sesuai dengan harapan dan tuntutan pendidikan masa depan, khususnya pada jenjang madrasah ibtidaiyah. Artinya, visi, misi, dan tujuan jurusan PGMI sudah baik dan mengarah kepada kemampuan dasar seorang pendidik serta menekankan pada akhlaqul karimah. Kemampuan dasar yang dimaksud

Sementara itu, pada aspek profil lulusan jurusan PGMI, kepala madrasah MI di Kota Cirebon juga merespon sudah sesuai dengan kebutuhan stakeholders. Namun kompentensi lulusannya perlu ditingkatkan. Agar lulusan Jurusan PGMI IAIN Syekh Nurjati Cirebon mampu berkompetisi dengan lulusan dari jurusan PGSD/PGMI lainnya serta mampu berinovasi dalam mengajar.

Selanjutnya, pada aspek capaian pembelajaran, kepala madrasah MI di Kota Cirebon merespon sudah sesuai dengan bahan kajian yang diperlukan. Bahan kajian sudah baik dan memadai apabila diterapkan dalam proses pembelajaran di kelas maupun di luar kelas. 
Kemudian pada aspek komponen mata kuliah, kepala madrasah MI di Kota Cirebon merespon sudah sesuai dengan kebutuhan stakeholders. Namun konten pada setiap mata kuliah perlu dipertajam agar penguasaan pengetahuan mahasiswa lebih mendalam. Selain itu, juga perlu ditambahkan lagi mata kuliah baru, yakni mata kuliah psikologi kepribadian dan hubungan sosial agar lulusan jurusan PGMI lebih mampu untuk berinteraksi dengan civitas akademika di sekolah dasar/madrasah ibtidaiyah.

Pada aspek bobot sks mata kuliah, kepala madrasah MI di Kota Cirebon merespon sudah cukup sesuai. Akan tetapi mereka menyarankan agar untuk mata kuliah keahlian profesi (dalam hal ini perencanaan pembelajaran) serta mata kuliah yang bersifat praksis seperti PPL (praktik pengalaman lapangan) perlu ditambah bobot sks nya, agar lulusan jurusan PGMI lebih unggul dan berkualitas dibandingkan dengan lulusan jurusan yang sejenis serta mampu memenuhi kebutuhan masyarakat. Hal ini juga didasarkan pada hasil evaluasi praktik pengalaman lapangan (PPL) dari mahasiswa praktikan jurusan PGMI. Kemudian terkait dengan aspek softskill yang dikembangkan di setiap mata kuliah, kepala madrasah MI di Kota Cirebon merespon sudah sesuai.

Selanjutnya, terkait dengan deskripsi mata kuliah, kepala madrasah MI di Kota Cirebon merespon sudah sesuai dengan keluasan dan kedalaman mata kuliah tersebut. Terakhir, pada aspek penempatan mata kuliah pada setiap semester, menurutnya sudah sesuai, karena sudah hirarkis dan sistematis.

Dari uraian hasil wawancara di atas dapat disimpulkan bahwa respon kepala madrasah MI di Kota Cirebon terhadap kurikulum berbasis KKNI jurusan PGMI sudah baik dan layak diimplementasikan di jurusan PGMI Fakultas Ilmu Tarbiyah dan Keguruan IAIN Syekh Nurjati Cirebon. Namun ada sedikit yang perlu direvisi, yakni penambahan satu mata kuliah baru, yakni psikologi kepribadian dan hubungan sosial serta penambahan bobot sks pada mata kuliah keahlian profesi seperti perencanaan pembelajaran dan praktik pengalaman lapangan.

\section{Respon Kementerian Agama Kota Cirebon Terhadap Kurikulum Berbasis KKNI Jurusan PGMI}

Berdasarkan hasil wawancara dengan pihak Kasi Pendidikan Madrasah/Sekolah Kementerian Agama Kota Cirebon diperoleh bahwa respon Kasi Pendidikan Madrasah/Sekolah Kementerian Agama Kota Cirebon terhadap kurikulum berbasis KKNI jurusan PGMI pada aspek visi, misi, dan tujuan sudah sangat sesuai. Menurutnya, visi, misi, dan tujuan jurusan PGMI sudah sesuai dengan kebutuhan masyarakat dalam rangka mencetak lulusan yang profesional. 
Sementara itu, pada aspek profil lulusan jurusan PGMI, Kasi Pendidikan Madrasah/Sekolah Kementerian Agama Kota Cirebon juga merespon sudah sesuai. Profil lulusan jurusan PGMI sudah sesuai dengan kebutuhan pasar "marketable", yakni lulusan jurusan PGMI tidak hanya diarahkan untuk menjadi guru kelas saja, tetapi juga diarahkan untuk menjadi peneliti dan edutainment.

Selanjutnya, pada aspek capaian pembelajaran Kasi Pendidikan Madrasah/Sekolah Kementerian Agama Kota Cirebon merespon sudah sesuai dengan bahan kajian yang diperlukan. Bahan kajian sudah baik dan tepat serta sesuai dengan kurikulum 2013 yang diterapkan di Madrasah/sekolah. Kemudian pada aspek komponen mata kuliah, Kasi Pendidikan Madrasah/Sekolah Kementerian Agama Kota Cirebon merespon sudah sesuai dengan kebutuhan stakeholders. Menurutnya mata kuliah yang diajarkan di jurusan PGMI sudah mengacu KKNI dan SNPT.

Pada aspek bobot sks mata kuliah, Kasi Pendidikan Madrasah/Sekolah Kementerian Agama Kota Cirebon merespon sudah sesuai. Menurutnya, mata kuliah penciri jurusan PGMI (Fiqih, Qur'an Hadits, Aqidah Akhlaq, Sejarah Peradaban Islam, dan lain sebagainya) agar lulusan jurusan PGMI memiliki akhlaqul karimah. Kemudian terkait dengan aspek softskill yang dikembangkan di setiap mata kuliah, Kasi Pendidikan Madrasah/Sekolah Kementerian Agama Kota Cirebon merespon sudah sesuai.

Terkait dengan deskripsi mata kuliah, Kasi Pendidikan Madrasah/Sekolah Kementerian Agama Kota Cirebon merespon sudah sesuai dengan keluasan dan kedalaman mata kuliah tersebut. Terakhir, pada aspek penempatan mata kuliah pada setiap semester, menurutnya sudah sangat sesuai, karena sudah hirarkis dan sistematis.

Dari uraian hasil wawancara di atas dapat disimpulkan bahwa respon Kasi Pendidikan Madrasah/Sekolah Kementerian Agama Kota Cirebon terhadap kurikulum berbasis KKNI jurusan PGMI sudah baik dan sangat layak diimplementasikan di jurusan PGMI Fakultas Ilmu Tarbiyah dan Keguruan IAIN Syekh Nurjati Cirebon.

Dari hasil penelitian yang telah diuraikan di atas menunjukkan bahwa secara umum respon stakeholders (dosen jurusan PGMI, Kepala MI Kota Cirebon, dan Kasi Pendidikan Madrasah Kementerian Agama Kota Cirebon) terhadap kurikulum berbasis KKNI jurusan PGMI sudah baik dan sangat layak diimplementasikan di jurusan PGMI. Kelayakan kurikulum berbasis KKNI jurusan PGMI Fakultas Ilmu Tarbiyah dan Keguruan IAIN Syekh Nurjati Cirebon tersebut tentu karena kurikulum jurusan PGMI sudah memenuhi karakteristik kurikulum berbasis KKNI. Hal ini sesuai dengan penelitian yang telah dilakukan oleh (Setiawan, 2017) yang mengungkapkan bahwa karakteristik kurikulum berorientasi KKNI diantaranya adalah adanya capaian program studi, capaian pembelajaran, 
kesesuaian antara kemampuan akhir yang diharapkan, pengalaman belajar dan kriteria penilaian yang terdapat pada display kegiatan.

Di samping itu, kurikulum berbasis KKNI Jurusan PGMI juga sudah sesuai dengan kebutuhan masyarakat, yakni sudah mengarahkan mahasiswa jurusan PGMI untuk menguasai kompetensi-kompetensi yang dibutuhkan di masyarakat, baik sebagai pendidik maupun yang lainnya. Hal ini senada dengan penelitian yang dilakukan oleh (Solikhah, 2015) yang mengungkapkan bahwa kompetensi KBK dalam perguruan tinggi terdiri dari kompetensi utama, kompetensi pendukung dan kompetensi lain yang bersifat khusus dan gayut dengan kompetensi utama.

Selanjutnya kurikulum berbasis KKNI jurusan PGMI sudah menekankan pada penguasaan level/jenjang KKNI untuk strara 1 (sarjana) yakni level analisis, sintesis dan create. Hal ini dapat dilihat dari learning outcomes yang terdapat pada kurikulum berbasis KKNI Jurusan PGMI. Secara umum learning outcomes yang ada sudah mengarahkan mahasiswa untuk mampu mengidentifikasi masalah, menganalisis masalah, dan memecahkan masalah. Sebagaimana yang diungkapkan oleh (Ennis, 2011) dalam penelitiannya bahwa indikator kemampuan berpikir kritis meliputi (1) menganalisis pertanyaan, (2) memfokuskan pertanyaan, (3) mengidentifikasi asumsi, (4) menulis jawaban atau solusi dari permasalahan soal, (5) menarik kesimpulan dari solusi permasalahan yang telah diperoleh, dan (6) menentukan alternatif-alternatif cara lain dalam menyelesaikan masalah.

\section{SIMPULAN}

Berdasarkan uraian hasil penelitian di atas, dapat disimpulkan sebagai berikut:

1. Respon dosen jurusan PGMI terhadap kurikulum berbasis KKNI jurusan PGMI sudah baik dan sangat layak diimplementasikan di jurusan PGMI Fakultas Ilmu Tarbiyah dan Keguruan IAIN Syekh Nurjati Cirebon. Draft kurikulum berbasis KKNI jurusan PGMI sudah mengarahkan mahasiswa jurusan PGMI untuk menguasai empat kompetensi seorang pendidik, yakni kompetensi kepribadian, kompetensi profesional, kompetensi paedagogik dan kompetensi sosial. Selain itu, draft kurikulum berbasis KKNI jurusan PGMI juga sudah menekankan pada penguasaan level/jenjang KKNI untuk strara 1 (sarjana) yakni level analisis, sintesis dan create.

2. Respon kepala madrasah MI di Kota Cirebon terhadap kurikulum berbasis KKNI jurusan PGMI sudah baik dan layak diimplementasikan di jurusan PGMI Fakultas Ilmu Tarbiyah dan Keguruan IAIN Syekh Nurjati Cirebon. Namun ada sedikit yang perlu direvisi, yakni penambahan satu mata kuliah baru, yaitu psikologi kepribadian dan hubungan sosial serta 
penambahan bobot sks pada mata kuliah keahlian profesi seperti perencanaan pembelajaran dan praktik pengalaman lapangan.

3. Respon Kasi Pendidikan Madrasah/Sekolah Kementerian Agama Kota Cirebon terhadap kurikulum berbasis KKNI jurusan PGMI sudah baik dan sangat layak diimplementasikan di jurusan PGMI Fakultas Ilmu Tarbiyah dan Keguruan IAIN Syekh Nurjati Cirebon.

\section{DAFTAR PUSTAKA}

Arifin, Z. (2011). Penelitian Pendidikan; Metode dan Paradigma Baru. Bandung: Rosdakarya.

Arifuddin, M. A., \& Fatimah, T. (2016). Respon Dosen terhadap Kebijakan Implementasi Kurikulum 2013 di Sekolah/Madrasah (Studi Pada Dosen FTIK IAIN Palu). ISTIQRA Jurnal Penelitian Ilmiah, 4(2).

Ennis, R. (2011). The Nature of Critical Thinking: Sn Outline of Critical Thinking Dispositions and Abilities. Sixth International Conference on Thinking at MIT (pp. 1-8). Cambridge: MA.

Hasan, I. (2015). Pengembangan Kurikulum LPTK (Penyiapan Calon Guru PAI) Berbasis KKNI. Islamadina, 14(1), 29-49.

Hasbiansyah, O. (2008). Pendekatan Fenomenologi: Pengantar Praktik Penelitian dalam Ilmu Sosial dan Komunikasi. Mediator: Jurnal Komunikasi, 9(1), 163-180.

Hatten, K., \& Rosental. (2001). Reaching For The Knowledge Edge. New Yor: American Management Assosiation.

Khodijah, N. (2016). Ketepatan Penyusunan Kurikulum Prodi MPI Fakultas Ilmu Tarbiyah dan Keguruan UIN Raden Fatah Dikaitkan dengan KKNI, SN-DIKTI, dan Panduan Penyusunan Kurikulum Pendidikan Tinggi Tahun 2014. El-Idare: Jurnal Manajemen Pendidikan Islam, 2(1), 80-199.

Moloeng, L. J. (2000). Metode Penelitian Kualitatif. Bandung: Rosdakarya.

Nurdiani, N. (2014). Teknik Sampling Snowball dalam Penelitian Lapangan. Comtech, 5(2), $1110-1118$.

Peraturan Presiden RI No 8. (2012). Kerangka Kualifikasi Nasional Indonesia. Jakarta: tp.

Permendikbud RI No 73 . (2013). Penerapan Kerangka Kualifikasi Nasional Indonesia Bidang Pendidikan Tinggi. Jakarta: Kemdikbud.

Setiawan, D. (2017). Pengembangan Model Kurikulum Berorientasi KKNI di Fakultas Ilmu Sosial Universitas Negeri Medan. Prosiding Seminar Nasional Tahunan Fakultas Ilmu Sosial Universitas Negeri Medan (pp. 581-586). Medan: Fakultas Ilmu Sosial Universitas Negeri Medan.

Soegiyono. (2013). Metode Penelitian Pendidikan: Pendekatan Kuantitatif, Kualitatif, dan R\&D. Bandung: Alfabeta.

Solikhah, I. (2015). KKNI dalam Kurikulum Berbasis Learning Outcomes. Jurnal Lingua, 12(1), $1-22$.

Supriyadi, E. (2012). Kajian Kurikulum Jurusan Pendidikan Teknik Elektro Fakultas Teknik Universitas Negeri Yogyakarta Mengacu Pada KKNI. Jurnal Pendidikan Teknologi dan Kejuruan, 21(2), 156-166. 
Sutrisno \& Suyadi. (2015). Desain Kurikulum Pendidikan Tinggi Berbasis KKNI. . Yogyakarta: tanpa penerbit.

Waseso, H. P., \& Hidayat, M. S. (2017). Penerapan Kurikulum Berbasis KKNI pada Prodi PGMI Unsiq Jawa Tengah. JIP: Jurnal Ilmiah PGMI, 3(1), 33-48.

Zulaikha, S., \& Khair, U. (2016). Respon Pihak Sekolah Terhadap Kompetensi Mahasiswa PPL Prodi PGMI STAIN Curup TA 2014/2015. Al Ibtida: Jurnal Pendidikan Guru MI, 3(1), 181-182. 